\title{
EQUALITY BEFORE THE LAW PRINCIPLE AND THE LEGAL AID FOR THE POOR: AN INDONESIAN INSIGHT
}

\author{
Khoirum Lutfiyah \\ Justice and Equality Forum \\ *Email: khoirumlutfiyah@gmail.com
}

\begin{abstract}
Legal aid is something that is given by the state to people who are unable to get justice and their basic rights before the law. The state has an obligation to protect every citizen, especially legal protection for the poor or the poor. To ensure this protection, the government forms a law which can help the underprivileged or poor in dealing with the legal problems they experience. With the existence of the Law on Advocacy, the Law on Legal Aid, as well as the existence of this Legal Aid Institute, it is hoped that it will be able to reduce the burden on what people experience before the law, especially related to the costs of legal aid.
\end{abstract}

Keywords: Underprivileged Community; Legal Aid; Poor People

The Indonesian Journal of International Clinical Legal Education DOI: https://doi.org/10.15294/ijicle.v3i4.48292

Submitted: Dec 12, 2020 Revised: March 13, 2021 Accepted: August 10, 2021 Available online at https://journal.unnes.ac.id/sju/index.php/iccle (C) 2021 Authors. This work is licensed under a Creative Commons AttributionShareAlike 4.0 International License (CC BY-SA 4.0). All writings published in this journal are personal views of the authors and do not represent the views of this journal and the author's affiliated institutions. 
Khoirum Luthfiyah

\section{INTRODUCTION}

In times like today, everything is certainly not easy to obtain. Especially when it comes to justice. Often we can see that to get what we need must be balanced with the presence of money to support and get what we want. However, what about people who can't afford it? To get legal aid, it seems that they have to spend quite a lot of money to help get justice.

Indonesia is a legal state that has an obligation to provide protection to its citizens related to the recognition of the human rights of each individual, this is stated in Article 1 paragraph (2) of the 1945 Constitution. Protection and recognition of human rights is an obligation for the state as a consequence of the determination as a state of law.

Basically, everyone has the same rights before the law, as referred to in 27 paragraph (1) of the 1945 Constitution which states that "Every citizen has the same position in law and government with no exceptions". According to one of the figures, Soerjono Soekanto, in essence legal aid is legal assistance provided by experts to the community to obtain their rights and receive equal and reasonable legal protection. ${ }^{1}$ Equal status before the law for every citizen is the principle of equality before the law, in which a person has the right to be treated equally before the law, especially the poor.

To obtain legal assistance, it can be obtained from the Legal Aid Institute. The Legal Aid Institute itself is an embodiment of one of the important principles adopted by the Criminal Procedure Code or what can be called (KUHAP), namely the accusatoir principle or the principle which shows that the accused being examined in court is not considered an object, but is considered a subject. This principle has indicated an open examination where everyone can attend or witness the process or the course of the examination. The rights of the accused are the same as those

1 IGN. Ridwan Widyadharma, Profesional Hukum dalam Pemberian Bantuan Hukum, Semarang: Badan Penerbit Universitas Diponegoro, 2010, pp. 26-27. Equality Before the Law is a very universal (applicable anywhere) and textual concept for law. Universally, Equality Before the Law has become a law and state principle that requires the existence of a law and applies it to everyone. Whereas textual, Equality Before the Law is written in a legal document which is the parent of the rule of law which confirms that the rule of law applies to everyone where the law applies. On the other hand, from a legal perspective, the law does not allow itself to only benefit several parties without a valid reason before the law. If there are exceptions, then it betrays the concept of law. See also Daron Acemoglu, and Alexander Wolitzky. "A theory of equality before the law." The Economic Journal Vol. 131 No. 636, 2021, pp. 1429-1465; Bambang Joyo Supeno, "Principle of Equality Before the Law and Diversion on Criminal Justice System for Children in Indonesia," UNTAG Law Review Vol. 4 No.1, 2020, pp. 69-80; Ndaru Satrio, and Faisal Faisal. "Hak Saksi dan Korban Tindak Pidana Kasus Tertentu dalam Perlindungan Saksi dan Korban Perspektif Equality Before The Law." Cepalo Vol. 5 No.1, 2021, pp. 1-10. 
of the public prosecutor, while the judge is above them to resolve the criminal case in accordance with applicable law. For the poor, of course, they find it difficult to get justice because of limited funds.

Law enforcement in a broad sense includes activities to implement and apply the law as well as take legal action against any violations or legal deviations committed by legal subjects, either through judicial procedures or through arbitration procedures and other dispute resolution mechanisms. In a broader sense, law enforcement activities include all activities intended so that the law as a set of normative rules that regulates and binds legal subjects in all aspects of social and state life is truly obeyed and truly carried out as it should. In a narrow sense, law enforcement involves taking action against any violation or deviation from the laws and regulations, especially through the criminal justice process involving officers such as the police, prosecutors, advocates and lawyers, as well as judicial bodies. ${ }^{2}$

\section{HOW IS THE PROVISION OF LEGAL AID IN INDONESIA?}

In its form, the law has two characteristics, namely, the first is unwritten where the law is the rule of law that lives in society which is often referred to as customary law. The second is a written law that is formed by an authorized institution and has witnesses and is coercive in nature which must be obeyed by all members of the community. From these two things, there are differences, namely in terms of form and witnesses. The form of unwritten law which is a rule made from generation to generation and the witnesses are not firm. While the written law has strict sanctions that must be obeyed by every citizen, and the maker of the regulation is a clear institution. In relation to law enforcement, according to one of the figures, namely Soerjono Soekanto, law enforcement can be influenced by several factors, such as: legal factors and statutory regulations; factors of law enforcement officers in other words related to the law-making process as well as those that are enforced; factors of facilities and infrastructure that support the law enforcement process; the factor of public awareness, namely in other words the application of law to the social environment; Cultural factors or often called the work, creativity and taste are based on social life. ${ }^{3}$

According to C.A.J Crul, legal aid is assistance provided by experts for those who need the realization or realization of their rights and obtain

2 Jimly Asshiddiqie, Gagasan Kedaulatan Rakyat dalam Konstitusi dan Pelaksanaannya di Indonesia, Jakarta: Ichtiar Baru-van Hoeve, 1994, pp. 34-35.

3 Diding Rahmat, Implementasi Kebijakan Program Bantuan Hukum Bagi Masyarakat Tidak Mamu di Kabupaten Kuningan, Jurnal Unifikasi, Vol. 4 No. 1, 2017, p. 36-37. 


\section{Khoirum Luthfiyah}

legal protection. ${ }^{4}$ According to Law Number 18 of 2003 concerning Advocates which explains that Legal Aid is a service provided by advocates free of charge to clients who cannot afford it. Then according to Law Number 16 of 2011 concerning Legal Aid which explains that Legal Aid is a legal service provided by Legal Aid Providers free of charge to Legal Aid Recipients. In addition, according to Adnan Buyung Nasution, legal aid is a special legal aid given to low-income groups or in other words the poor, where the size of the poor is still difficult to solve, not only from developing countries, but also from developing countries. progress is still difficult to solve poverty. ${ }^{5}$

In this legal aid, in its concept there are 4 applications, namely as follows:

1. The concept of traditional legal aid, is a legal service provided to the poor individually, which is passive and the approach is formal-legal;

2. The concept of constitutional legal aid, namely legal aid for underprivileged communities carried out within the framework of broader business and objectives, such as, people who are unable to be made aware of their rights as legal subjects, development and enforcement of human rights values as the main thing for the establishment of a state of law; ${ }^{6}$

3. The concept of structural legal aid, is an activity that has the aim of establishing conditions for realizing laws that can change an overlapping structure towards a more just structure, where the place of legal regulations and their implementation can guarantee equality of position both in the legal field and in the political sphere. This concept is closely related to structural poverty; ${ }^{7}$

4. Responsive legal aid is assistance provided to the poor free of charge which includes all fields of law and human rights, and without distinguishing between individual and collective defense cases. In this responsive legal aid, the services provided are in the form of counseling on a law related to human rights and the legal process for the right to be defended by legal aid organizations and advocates. This defense, in overcoming real legal problems, is qualified in court in order to produce a law that is firm, precise, clear and true. Legal reform through a court decision, which favors the truth and the formation of a law that is in accordance with the value system and culture that exists in society in order to make this a success, legal aid

4 Soerjono Soekanto, Bantuan Hukum, Suatu Tinjauan Sosio-Yuridis, Jakarta: Ghalia Indah, 1983, p. 23

5 Adnan Buyung Nasution, Bantuan Hukum Di Indonesia, Bantuan Hukum Dan Politik Pembangunan, Jakarta: LP3ES, 2007, pp. 1-3

6 YLBHI, Panduan Bantuan Hukum di Indonesia, Jakarta: Yayasan Obor Indonesia, 2014, p. 462.

7 Suradji, Etika dan Penegakan Kode Etik Profesi Hukum (Advokat), Jakarta: Badan Pembinaan Hukum Nasional Departemen Hukum dan HAM, 2008, pp. 77-78. 
must become a national movement which of course can be supported by the state and its own people. ${ }^{8}$

We need to know, the poor or the poor are exceptions to the law which, according to them, often feel they do not get justice and close their opportunities to improve their standard of living, and this often happens in various developing and poor countries in the world. These poor people or poor people usually work outside the scope of the law, such as workers who work on contract, people who carry out registered land businesses and occupy land without being accompanied by official or legal identity or documents. They are the ones who are vulnerable to problems related to the law and usually do not get legal or other assistance from the state when their rights are violated. Poverty itself, literally comes from the word poor which means not having property. Poverty in a broader sense means a state of inadequacy either individually, in families, or in groups. So this situation is very easy to cause a social problem. Poverty is a condition in which a person or group of people whose basic rights are not properly fulfilled to obtain a dignified life, in other words, today's poverty is no longer seen from an incapacitated economic situation, but in terms of failure to fulfill basic rights and different treatment experienced. by someone in life. The view of poor life, not only in terms of lack of meeting the needs of food and clothing, but also comes from science, technology, and information obtained by the person, so that this causes unfair treatment of a person, and many problems arise.

Based on this, the state becomes an important aspect in providing Legal Aid which in this case according to the Legal Aid Act there are rights to determine who can provide legal assistance to underprivileged or poor community groups, one of which is the advocate profession. The provision of legal assistance in the Law on Advocates is something that is inherent in the profession whose function is to serve the community in matters related to the law. Apart from advocates, it turns out that there are also Law Faculty Students, Law Faculty Lecturers, and Paralegals who have met the requirements who can provide legal assistance as stated in the Legal Aid Act (Article 8). However, this is still a problem because it is different from the Law on Advocates which explains that anyone who carries out a profession like an advocate but is not an advocate can be punished (Article 31). In the Law on Advocates itself, it regulates how the requirements, rights, and obligations to become someone who works as an advocate, in which there is supervision of the implementation of this profession in providing legal services.

8 Frans Hendra Winata, 2009, Probono Publico, Hak Konstitusional Fakir Miskin Untuk Memperoleh Bantuan Hukum, Jakarta: PT. Gramedia Pustaka Utama, 2009, p. xii 


\section{WHAT ARE THE OBSTACLES STILL FACED IN PROVIDING LEGAL AID IN INDONESIA?}

In the provision of legal aid to the underprivileged or the poor, there are still various kinds of problems that exist, such as in the normative legal framework regarding the provision of legal aid that is practiced in the community, especially for the poor which is still not carried out optimally by advocates. as a legal aid provider. As for the things of the behavior of advocates in dealing with legal aid issues for the poor, namely as follows, advocates avoid with various reasons so as not to accept the case, want to accept a case but on the grounds that the case must attract the attention of the mass media so that the advocate becomes well-known, and can fully accept to provide legal assistance. Advocates like this prefer to defend clients and accept cases from the upper classes rather than the poor. This is what causes the advocate profession to be unfavorable in the eyes of the public. ${ }^{9}$

Based on several studies that have been carried out by previous researchers, it is stated that almost some advocates are reluctant to provide assistance in defending the underprivileged by rejecting cases unobjectively. The objective in question is the rejection of cases that are not legal problems, in the sense that the problem is not included in the category of legal problems that cause or cause legal consequences.

Advocates are not objectively refusing based on the results of research conducted by previous researchers, such as rejecting cases of sexual harassment, fighting the government, or even refusing the case because the case is not a big case that will not be published by the mass media. The non-objective rejection of cases experienced by the poor by advocates is a deviation from the normative legal framework of providing legal aid, because normatively legal aid is given without knowing what legal problems will be handled and who will be defended, but how the poor get the right to access. to law and justice when the poor are in trouble with the law. When the normative framework for providing legal aid is not carried out by advocates, the law regarding legal aid does not become law, in other words, regulations regarding legal aid are just a myth created by the state.

Ignorance of the law will result in someone breaking the law or someone being fooled by an individual to take advantage, and what is more surprising is that the person is usually from law enforcement or the government. In the opinion of John Rawls "all legal systems will fail if they are not encouraged by a genuine personal moral attitude (justice as

9 Marudut Tampubolon, Membedah Profsi Advokat, Perspektif Ilmu Sosial Interaksi Advokat-Klien, Yogyakarta: Pustaka Pelajar, 2014, pp. 133-134 
farness) in society." Based on this opinion, if it is clashed with the application of legal aid for the underprivileged or poor, if the poor in practice still lack legal awareness and legal knowledge of the importance of legal aid, then the provision of legal aid will not function optimally. The perspective of the application of providing legal aid for the poor or underprivileged, is not only seen as meeting the community's need for assistance in every legal process, but more than that, namely making the community understand the law and be able to criticize existing legal products, namely by providing legal education and citizenship for society. This perspective can ideally solve this problem, but it is not yet appropriate at the level of implementation. There are still some lawyers and legal aid institutions who still tend to view the provision of legal aid as passive.

The perspective of providing passive legal aid can be a burden on the optimization of the provision of legal aid. It can be described as, the provision of legal assistance provided by advocates/LBH on the appointment of the police or court as legal advisors due to the provision of funds from the court and cases whose sentences are above 15 years in prison as recommended by the Criminal Procedure Code. Based on Perma No. 1 of 2014 concerning Guidelines for Providing Legal Services for Underprivileged Communities in Courts, court institutions provide a budget to provide free legal aid and establish a Legal Aid Post (Posbakum). Access to legal aid provided by the court by appointing an advocate/LBH funded by the court, this is called institutional cooperation (Article 26 of Perma No. 1 of 2014) while Posbakum itself functions to provide legal consulting services, making the required legal documents and information on advocates/LBH who receive legal assistance (Article 25 of Perma No. 1 of 2014). The presence of access to legal aid is not without problems, the problem that arises is the 'limitation of the budget provided' so that if the allotted budget has been absorbed, then there are cases from underprivileged communities that require free legal aid or the case needs to be brought to the court of appeal, cassation or reconsideration can be simply ignored, because the budget provided has been completely absorbed. This will raise the next problem. Based on the perspective that the provision of legal aid is passive, and the limited access provided by the court will reduce the optimization of the provision of legal aid for the poor. This makes the urgency of the sensitivity of advocates/LBH to view the provision of legal aid actively and not rely too much on the access provided by the court. ${ }^{10}$

Starting from the sentence "the blade of the law is sharper down than up" which means that the sense of justice from the law does not touch the lower classes, while those who have a higher social class will easily get more preferential treatment. Errors in the application of law

10 Perma Nomor 1 Tahun 2014 tentang Pedoman Memberikan Layanan Hukum Bagi Masyarakat Tidak Mampu di Pengadilan 


\section{Khoirum Luthfiyah}

and legal subjects made by judges as controllers of the court process are not rare in judicial practice in Indonesia, this is what is called a deviant judiciary. Often in practice in the community, especially the poor people experience/become victims of a deviant judiciary, although there is access to an appeal, cassation, or review to avoid a deviant trial, this access is not yet possible for the poor to use because it will cost the poor a lot of money. to be paid. Based on this, the existence of the Legal Aid Law is not a guarantee for the poor to get access to appeal, cassation or review. This is because at the level of practice in society, the application of legal aid is only a formality by some advocates and LBH. Based on the results of the research conducted, some of the provision of legal aid is carried out to the courts of the first instance. From the point of view of an advocate/LBH, this is done on the basis of the client's request, but from the point of view of the poor or poor people request (no appeal, cassation, review) on the basis of submission and do not have the cost to access it.

A matter that becomes a dilemma, where the Law on Legal Aid requires to provide legal aid for the poor free of charge sourced from the APBN and APBD and Perma No. 1 of 2014 which is sourced from the local court budget, normatively legal aid is purely free, without any other costs, but this is not consistent in the world of practice in the community, where the poor or the poor are still charged fees such as photocopying fees, summoning witnesses and experts, as well as transportation costs are the responsibility of the poor in receiving legal aid. The fee collection is carried out on the basis of supporting the work of an advocate or LBH. In fact, collecting fees for legal aid is a prohibition with a maximum imprisonment of 1 year and a fine of fifty million rupiah (Article 20 in conjunction with Article 21 of the Law on Legal Aid). This becomes a dilemma in the application of legal aid for the poor. Talking about funding or money is an interesting thing, because with that all work activities will be easy and because it can also change an ideology. Funding in legal aid is a form of responsibility and enthusiasm given to the state to advocates/LBH because it is obligatory to provide legal aid to the poor or underprivileged.

The Law on Legal Aid provides funding for advocates/LBH with a variety of complicated conditions and procedures. The conditions given are more likely to be fulfilled by LBH alone, and even then, there must be a selection process commonly referred to as accreditation as legitimacy to absorb the legal aid funding, this has the tendency of discrimination. Based on research conducted by previous researchers, the results of verification and accreditation in 2013, there were only 310 organizations that passed. This figure is very small, so there are still LBHs that do not pass accreditation, especially in the areas of Papua, Bali, NTT, NTB. Not to mention that the procedure for absorbing these funds is very complicated, because the funding is delegated to the 
Ministry of Law and Human Rights whose legal position (office area) only exists in each province. This means that LBH domiciled in cities far from the province will find it difficult to access these funds.

Regarding the obstacles in the provision of legal aid, it can be seen from several things, such as the following:

1. There is no supervision in the application of legal aid.

Supervision is the most important thing to keep from overstepping or abusing. Starting from the absence of supervision in the application of legal aid both normatively and in implementation in the community, it is necessary to have a supervisory system to oversee several components of the application of legal aid. This supervision includes whether legal aid is provided, whether or not access to justice is used, the performance of advocates or LBH in providing legal aid, in this case, of course, an opinion is needed from the public and clients who have been recipients of legal aid, and the final supervision regarding the absorption of legal aid. funds that see whether the funds used for legal aid are appropriate or not, so that there is no embezzlement or corruption of legal aid funds. After the material under supervision is known, what is no less important is the supervisor, which can consist of the government, advocate organizations and the community. Based on this, if the idea of 5 (five) efforts to optimize the provision of legal aid for the poor has been accepted and carried out, then it is not impossible that access to law and justice will be realized for the underprivileged or poor.

2. Active, Responsive and Structural Legal Aid.

The urgency in changing the orientation of legal aid to be active, responsive, and structural is needed because of the limitations of clients (the poor or the poor) who do not yet have the knowledge and awareness of the law and budget provided by the courts and the state. Being activeresponsive means that advocates must know more about the client's needs when there are legal problems without having to wait for requests from clients, law enforcement officers, or courts. Structural nature here means that advocates in providing legal assistance are not only to solve problems in court (legal advisors), but advocates / LBH make their clients understand the law more so that a structural legal awareness is created, this place advocates other than as advisors. law as well as legal mentor.

3. Purifying the Meaning of Free in Providing Legal Aid.

The provision of free legal aid is not something that is impossible to achieve, when a policy and procedure mechanism can be changed to make it easier to absorb legal aid funds, both from the APBN, APBD and the court (Supreme Court). These changes can be started from the accreditation procedure and the mechanism for the absorption of legal aid funds to make it easier without compromising the quality, so that it can be accessed by every advocate/LBH and advocate organization. The convenience provided can be in the form of establishing a branch office/institution that takes care of the absorption of legal aid funds in 


\section{Khoirum Luthfiyah}

each city/regency because so far, the absorption of funds must be managed at the regional office in the province, besides waiting for the establishment of branches in each city/regency can be combined by maximizing online, both through the system and human resource training. When the accreditation procedure and the mechanism for the absorption of legal aid funds have been simplified, it is not impossible to realize the meaning of free legal aid for the poor. This means that advocates/LBH will not hesitate in providing free legal aid, because the absorption of funds can help revive their work activities.

In addition to advocates, the role of paralegals in the provision of legal aid is also very necessary. To fulfill the need for the right to legal aid for every poor person who is in conflict with the law and to overcome the uneven distribution of legal aid providers, of course, the role of paralegals is needed to handle non-litigation cases. as well as litigation. As according to Rikardo Simarmata as quoted by Wiratraman, "Paralegals emerged in the long journey of working legal aid institutions, playing an important role in facilitating the formation of people's organizations, educating, raising awareness, conducting social analysis, advocacy, assisting lawyers, mediating and collecting documentation. Paralegals are assistant lawyers who practice and serve clients who are facing legal problems. Furthermore, Warjiyati explained that: "In some countries such as the United States, legal experts recognize that legal is a profession that is directly under the supervision of lawyers. But in the UK defined profession is not a lawyer but doing legal work regardless of who does it. However, there is no consistent definition of paralegals such as: role and work, status, terms and conditions of work, training, regulations or anything so that each jurisdiction has to look at it individually." 11

A paralegal is someone who has basic knowledge of the law, both procedural law (formal) and material law and the motivation, attitude and skills to:

1. Implement educational programs so that the disadvantaged community groups are aware of their rights;

2. Facilitate the formation of people's organizations so that they can demand and fight for their rights;

3. Assist in mediation and reconciliation in the event of a dispute;

4. Conduct preliminary investigations into cases that occurred before being handled by lawyers;

5. Assisting lawyers in making statements (claims/defense), collecting required evidence and other information relevant to the case at hand.

The term paralegal can be found in the formulation of Articles 9 and 10 of the UUBH, but the provisions of the UUBH do not provide a definition, function and authority of paralegals, as well as in the

11 Eka N.A.M Sihombing, Eksistensi Paralegal dalam Pemberian Bantuan Hukum bagi Masyarakat Miskin, Jurnal Ilmiah Penegak Hukum, Vol. 6 No. 1, 2019, , pp 70-77 
provisions of the Permenkumham Paralegal which should regulate in more detail regarding paralegals, but unfortunately the definition of Paralegal is also not found. In the provisions of Article 2 of the Paralegal Pemerkumham it only states that the Paralegals regulated in this Ministerial Regulation are Paralegals who carry out the provision of legal aid and are registered with the Legal Aid Provider. Furthermore, the provisions of this Law and Human Rights Ministry also do not explicitly limit the Paralegal's authority in providing legal assistance, both litigation and non-litigation. So, it is only natural that some parties are worried that the role of paralegals will be able to replace and even take over the role of advocates, this is also the basis for testing the provisions of Article 11 and Article 12 of the Paralegal Permenkumham.

Based on the provisions of Article 11 and Article 12 of the Permenkumham Paralegal actually has the aim of fulfilling the right to legal assistance for the poor who are dealing with legal problems in all corners of the country which incidentally is not accommodated by the distribution of existing advocates. Thus, the role of paralegals in providing legal assistance in litigation should be strengthened, not delegitimized. which in the end has the effect of hampering the expansion of access to justice, especially for the poor who are facing legal problems.

The legal problems that ensnare many poor people or groups are currently increasingly complex, thus requiring the Government to immediately pay attention and regulate them in a planned, systematic, sustainable, and professional manner. ${ }^{12}$ Therefore, the Government Regulation of the Republic of Indonesia Number 42 of 2013 concerning Terms and Procedures for Providing Legal Aid and Distribution of Legal Aid Funds, as mandated by Article 15 paragraph (5) and Article 18 of Law Number 16 of 2011 concerning Legal Aid, which is part of the implementation of Legal Aid is directed to be the legal basis for the preparation of regulations for the implementation of Legal Aid in the regions and prevent the implementation of Legal Aid as an industrial practice that is solely profit-oriented and ignores the interests of the Legal Aid Recipients themselves. In this Government Regulation the provision of Legal Aid covers the criminal, civil, and state administrative areas, both in Litigation and Non-litigation which is fully carried out by Legal Aid Providers consisting of Legal Aid organizations. That the rules regarding Legal Aid Providers or Legal Aid organizations must be legal entities, is not intended to limit the constitutional rights and independence of the community in organizing, but this must be understood as a national strategy in professional, effective, and competitive organizational management as well as to facilitate effective cooperation and coordination, both with the Government and Regional

12 Jimly Assiddiqie, Konstitusi dan Konstitusionalisme Indonesia, Edisi Revisi, Jakarta: Konstitusi Press, 2005 


\section{Khoirum Luthfiyah}

Governments as well as among Legal Aid Providers or Legal Aid organizations.

With the clarity and firmness of the regulations regarding the requirements for the provision of Legal Aid, procedures for providing Legal Aid, budget submissions, disbursement of funds and accountability as well as based on the principles of availability, affordability, sustainability, trust, and accountability, it is hoped that this Government Regulation can increase the effectiveness and efficiency of the implementation of Aid. The law itself. The Legal Aid Program is an implementation of Law Number 16 of 2011 concerning Legal Aid. The state's obligations are contained in Law Number 16 of 2011 concerning Legal Aid. There are three parties regulated in this law, namely recipients of legal aid (poor people), legal aid providers (legal aid organizations) and legal aid providers (Ministry of Law and Human Rights of the Republic of Indonesia). Reporting on the rights of the poor who are neglected when dealing with legal processes has recently become a big topic that is being discussed. The rights of the poor who have been violated are not new in the public lawyer circles. Too many justice seekers who have come to various legal aid institutions, who rely on prodeo assistance, have experienced this. Unfortunately, the legal instruments that regulate the provision of legal aid to the people, especially the poor, are still limited. The Criminal Procedure Code only recognizes the provision of free legal aid to those who are threatened with imprisonment of 5 years or more. Less than that, you have to depend on your own fate or economy. For example, a scavenger like Saleh who "owns" marijuana, because he is forced, is not actually entitled to legal aid under the Criminal Procedure Code. Marijuana, which is classified as a class I narcotic, carries a penalty of 4 years to 12 years in prison. Moreover, the provision of legal aid is carried out at which level of examination, the regulation is also unclear. The government's intention to regulate the provision of legal aid through government regulations (PP) and regulations at the level of Ministerial Instructions has also not touched this problem. These regulations only provide a reference for the provision of legal aid and have not accommodated the rights of the poor to obtain legal aid. In addition, the Government Regulation which is a mandate of the Law on Advocates is not appropriate to regulate $\mathrm{LBH} /$ legal aid activists, whose character and function is different from that of advocates in terms of providing free legal aid. In essence, the provision of legal aid is not solely the responsibility of $\mathrm{LBH}$, advocates, or political parties that have some kind of legal aid division. It is stated in the constitution that everyone has the right to be treated equally before the law (equality before the law). Those who cannot afford it are clearly protected by the principle of "the poor and neglected children are cared for by the state" (Article 34 of the 1945 Constitution). Thus, the fulfillment of the right to legal aid, which is a very fundamental human 
right, is basically the responsibility of the state. Contrasting conditions with corruption trials and other cases involving high-ranking officials or people with a lot of money, which actually shows that the right to be accompanied by a high-class lawyer is a primary accommodation. As for the poor, it is difficult enough to get legal aid alone. This makes the right to recognition, guarantee, protection and fair legal certainty and equal treatment before the law seems to be something that is too grandiose. ${ }^{13}$

Legal Aid is a legal service provided by legal aid providers $(\mathrm{OBH})$ free of charge to legal aid recipients. The legal assistance provided includes criminal, civil and state administrative matters, both litigation and non-litigation. Litigation Legal Aid includes:

1. Criminal Cases, including investigations and trials at the first level court, appellate level trial, cassation level trial, and review;

2. Civil cases, including reconciliation efforts or court decisions at level I, court decisions at the appellate level, court decisions at the cassation level, and judicial review; and

3. State Administrative Cases, including preliminary examinations and court decisions at level I, court decisions at the appellate level, court decisions at the cassation level, and judicial review.

The provision of Litigation Legal Aid by the Legal Aid Provider to the Legal Aid Recipient is given until the legal problem is resolved and/or the case has permanent legal force, as long as the Legal Aid Recipient does not revoke the special power of attorney. Non-Litigation Legal Aid includes:

1. legal counseling;

2. legal consultation;

3. investigation of cases both electronically and non-electronically;

4. legal research;

5. mediation;

6. negotiation;

7. community empowerment;

8. assistance outside the court; nor

9. drafting of legal documents.

The National Legal Development Agency is appointed by the Ministry of Law and Human Rights of the Republic of Indonesia to carry out the Implementation of Legal Aid. Therefore, the National Legal Development Agency has a very important and strategic role to ensure that the implementation of legal aid is carried out in accordance with the principles stated in Article 2 of Law number 16 of 2011 namely:

1. Justice;

2. Equality before the law;

13 Isnandar Syahputra N, Urgensi Peran Pengadilan dalam Memberikan Pelayanan Bantuan Hukum Terhadap Orang Miskin Sesuai Undang-Undang Nomor 16 Tahun 2011 Tentang Bantuan Hukum, Jurnal Hukum dan Peradilan, Vol. 4, No. 1, 2015, pp. $171-188$ 


\section{Khoirum Luthfiyah}

3. Openness;

4. Efficiency;

5. Effectiveness;

6. Accountability. ${ }^{14}$

The mechanism for providing legal aid as mandated by Law Number 16 of 2011 concerning Legal Aid is as follows:

a. Terms of providing legal aid

1. submit a written application containing at least the identity of the Legal Aid Applicant accompanied by a brief description of the subject matter or problems encountered to be applied for;

2. Recipients of Legal Aid submit documents related to the case at hand;

3. Attach a poverty certificate from the kelurahan, village head, or an official at the same level as the person requesting Legal Aid

b. Provision of Legal Aid is carried out by a Legal Aid provider who must meet the following requirements:

1. Legal entity;

2. Accredited;

3. Have a permanent office or secretariat;

4. Have an administrator; as well as

5. Have a Legal Aid program.

There are procedures that need to be followed for the provision of legal assistance. The Legal Aid Applicant submits his/her request in writing to the Legal Aid Provider which contains at least:

1. The identity of an applicant for legal aid is evidenced by the existence of an identity card or KTP and other documents issued by the competent authority. In relation to the issue of the legal aid applicant who does not have an identity, the legal aid provider assists the legal aid applicant in obtaining a temporary address certificate or other documents from the authorized agency in accordance with the domicile of the Legal Aid Provider.

2. A brief description of the subject matter for which legal assistance is requested.

For the application for legal aid as referred to, the following must be attached:

a. Certificate of poverty from the kelurahan, village head, or an official at the same level as the legal aid applicant's residence. If the applicant for legal aid does not have a poverty certificate, then he/she can attach a Community Health Insurance Card, Cash Direct Assistance, Poor Rice Card, or other supporting documents as a substitute for the poverty certificate.

b. Documents related to the case. If the applicant does not have the requirements as intended by the legal aid provider.

$14 \quad$ Ibid. pp. 177-178 
Legal Aid Applicants who are unable to prepare a written application may apply orally. In the event that the application for Legal Aid is submitted orally, the Legal Aid Provider shall put it in written form. The application is signed or thumbprinted by the Legal Aid Applicant. The Legal Aid Provider must check the completeness of the requirements as referred to in Article 6 within 1 (one) working day after receiving the Legal Aid application file. In the event that the application for Legal Aid has met the requirements, the Legal Aid Provider is required to submit a written willingness or rejection of the application within a maximum of 3 (three) working days from the date the application is declared complete. In the event that the Legal Aid Provider expresses willingness, the Legal Aid Provider provides Legal Aid based on a special power of attorney from the Legal Aid Recipient. In the event that the application for Legal Aid is rejected, the Legal Aid Provider is required to provide the reasons for the refusal in writing within a maximum of 3 (three) working days from the date the application is declared complete. Provision of Legal Aid by Legal Aid Providers to Legal Aid Recipients is given until the legal problem is resolved and/or the case has permanent legal force, as long as the Legal Aid Recipient does not revoke the special power of attorney. Provision of Legal Aid in Litigation is carried out by Advocates who have the status as administrators of Legal Aid Providers and/or Advocates recruited by Legal Aid Providers.

Implementation of the Legal Aid Budget. Legal Aid Providers carry out Litigation and Non-litigation Legal Aid in accordance with the provisions stipulated in the Legal Aid implementation agreement and the provisions of the legislation. The distribution of Litigation Legal Aid funds is carried out after the Legal Aid Provider has completed the Case at each stage of the litigation process and the Legal Aid Provider submits a report accompanied by supporting evidence. The distribution of Legal Aid funds is calculated based on a certain percentage of the case rate in accordance with the standard costs of implementing Litigation Legal Aid as referred to in Article 21 of Government Regulation Number 42/2013. The distribution of Legal Aid funds at every stage of the litigation process does not eliminate the obligation of the Legal Aid Provider to provide Legal Aid until the case being handled is completed or has permanent legal force. The stages of the proceedings are the stages of handling cases in:

1. criminal cases which include investigations and trials in courts of first instance, trials at the appellate level, trials at the cassation level, and judicial review;

2. civil cases which include reconciliation efforts or court decisions at the first level, court decisions at the appellate level, court decisions at the cassation level, and judicial review; 


\section{Khoirum Luthfiyah}

3. state administrative cases, which include preliminary examinations and court decisions at the first level, court decisions at the appellate level, court decisions at the cassation level, and judicial review.

In this case, there is also the distribution of non-litigation legal aid funds after the Legal Aid Provider has completed at least 1 (one) activity in the Non-litigation activity package as referred to in Article 23 paragraph (3) of Government Regulation Number 42/2013 and submits a report accompanied by supporting evidence. The distribution of Legal Aid funds is calculated based on the tariff per activity according to the standard costs of implementing Non-litigation Legal Aid as referred to in Article 21 of Government Regulation Number 42/2013. The Minister is authorized to test the correctness of the invoice for the completion of the implementation of Legal Aid as the basis for the distribution of Litigation and Non-litigation Legal Aid funds as referred to in Article 27 and Article 28 of Government Regulation Number 42/2013. Further provisions regarding the procedure for the implementation of the distribution of the Legal Aid Budget are regulated by applicable regulations.

The government is trying to overcome the problem of the reluctance of advocates to help the poor because there are no economic benefits obtained by providing legal aid by issuing Law Number 16 of 2011 concerning Legal Aid. Through this law, the state provides funds for advocates who provide legal assistance to the underprivileged. ${ }^{15}$

Supervision from the Minister who supervises the provision of Legal Aid and distribution of Legal Aid funds. Supervision by the Minister is carried out by a work unit whose duties and functions are related to the provision of Legal Aid to the Ministry. The work unit in carrying out the supervision as referred to in Article 34 paragraph (2) of Government Regulation Number 42/2013 has the following duties:

1. Supervise the provision of legal aid and distribution of legal aid funds;

2. Receive reports of supervision conducted by the regional supervisory committee;

3. Receive reports from the public regarding alleged irregularities in the provision of legal aid and distribution of legal aid funds;

4. Clarify the alleged irregularities in the provision of legal aid and distribution of legal aid funds reported by the regional supervisory committee and the community;

5. Propose sanctions to the minister for irregularities in the provision of legal aid and distribution of legal aid funds;

6. Make a report on the implementation of supervision to the Minister.

The Minister in carrying out supervision in the regions forms a regional supervisory committee. The regional supervisory committee consists of representatives from the following elements:

15 Agus Raharjo, et.al, Akses Keadilan Bagi Rakyat Miskin (Dilema Dalam Pemberian Bantuan Hukum Oleh Advokat), MIMBAR HUKUM Vol. 27, No. 3, 2015, p. 442 
1. Regional office of the ministry;

2. Provincial government legal bureau;

Regional supervisory committees also have the following duties:

1. Supervise the provision of legal aid and distribution of legal aid funds;

2. Make periodic reports to the Minister through work units whose duties and functions are related to the provision of legal assistance to the Ministry;

3. Propose sanctions to the minister for irregularities in the provision of legal aid and distribution of legal aid funds through work units whose duties and functions are related to the provision of legal aid to the ministry.

The regional supervisory committee in making decisions prioritizes the principle of deliberation. In the event that deliberation is not reached, decisions are made based on a majority vote. The Minister at the suggestion of the supervisor may forward the findings of irregularities in the provision of Legal Aid and the distribution of Legal Aid funds to the authorized agency to be followed up in accordance with the provisions of the legislation. In the case of Recipients of Legal Aid at the Minister's account. obtain their rights in accordance with the provisions of Article 12 of Law Number 16 of 2011 concerning Legal Aid, Legal Aid Recipients may report the Legal Aid Provider to the Minister, the parent organization of the Legal Aid Provider, or to the competent authority. In the event that the Advocate of Litigation Legal Aid does not carry out the provision of Legal Aid as referred to in Article 13 until the case is completed or has permanent legal force, the Legal Aid Provider is obliged to find a substitute Advocate. In the event that a violation of the provision of Legal Aid by the Legal Aid Provider to the Legal Aid Recipient is found, the Minister may:

1. Canceling the agreement for the implementation of Legal Aid;

2. Stop the granting of the Legal Aid Budget; and/or

3. Not providing Legal Aid Budget in the following fiscal year.

In the event that the Minister cancels the agreement as referred to in number 1 above, the Minister appoints another Legal Aid Provider to accompany or exercise the power of the Beneficiary.

\section{CONCLUSION}

This study concluded that in developing countries such as Indonesia, justice for the underprivileged is still difficult to obtain. There are various reasons for advocates who are reluctant to provide legal assistance, including those related to costs which advocates must provide free of charge to underprivileged communities which results in advocates not benefiting. In addition, for cases experienced by the underprivileged or 


\section{Khoirum Luthfiyah}

the poor, it must be on condition that the case attracts media attention so that the advocates used by the community are unable to assist them in providing legal aid to become famous. This is very unfortunate and makes the image of advocates bad. Therefore, the government established Law No. 18 of 2003 concerning Advocates, which regulates and supervises the advocate profession. Not only that, to realize the obligations of a state in which the state must protect the rights of its citizens, then enacted Law Number 16 of 2011 concerning Legal Aid which is given free of charge to the people, especially those who are unable to protect their rights.

\section{REFERENCES}

Acemoglu, D., \& Wolitzky, A. (2021). A theory of equality before the law. The Economic Journal, 131(636), 1429-1465.

Asshiddiqie, J. (1994). Gagasan Kedaulatan Rakyat dalam Konstitusi dan Pelaksanaannya di Indonesia. Jakarta: Ichtiar Baru-van Hoeve.

Assiddiqie, J. (2005). Konstitusi dan Konstitusionalisme Indonesia. Jakarta: Konstitusi Press.

Eka, N. M. A. S. (2019). Eksistensi Paralegal dalam Pemberian Bantuan Hukum bagi Masyarakat Miskin, Jurnal Ilmiah Penegak Hukum, 6(1), 70-77

Nasution, A. B. (2007). Bantuan Hukum di Indonesia, Bantuan Hukum dan Politik Pembangunan. Jakarta: LP3ES.

Nasution, I. S. (2015). Urgensi Peran Pengadilan dalam Memberikan Pelayanan Bantuan Hukum terhadap Orang Miskin Sesuai Undang-Undang Nomor 16 Tahun 2011 tentang Bantuan Hukum. Jurnal Hukum dan Peradilan, 4(1), 171-188.

Perma Nomor 1 Tahun 2014 tentang edoman Memberikan Layanan Hukum Bagi Masyarakat Tidak Mampu di Pengadilan

Raharjo, A., Angkasa, A., \& Bintoro, R. W. (2015). Akses Keadilan Bagi Rakyat Miskin (Dilema dalam Pemberian Bantuan Hukum oleh Advokat). Mimbar Hukum-Fakultas Hukum Universitas Gadjah Mada, 27(3), 432-444.

Rahmat, D. (2017). Implementasi Kebijakan Program Bantuan Hukum Bagi Masyarakat Tidak Mampu di Kabupaten Kuningan. UNIFIKASI: Jurnal Ilmu Hukum, 4(1), 35-42.

Satrio, N., \& Faisal, F. (2021). Hak Saksi dan Korban Tindak Pidana Kasus Tertentu dalam Perlindungan Saksi dan Korban Perspektif Equality Before The Law. Cepalo, 5(1), 1-10.

Soekanto, S. (1983). Bantuan Hukum, Suatu Tinjauan Sosio-Yuridis. Jakarta: Ghalia Indah. 
Supeno, B. J. (2020). Principle of Equality Before the Law and Diversion on Criminal Justice System for Children in Indonesia. UNTAG Law Review, 4(1), 69-80.

Suradji, S. (2008). Etika dan Penegakan Kode Etik Profesi Hukum (Advokat). Jakarta: Badan Pembinaan Hukum Nasional Departemen Hukum dan HAM.

Tampubolon, M. (2014). Membedah Profesi Advokat, Perspektif Ilmu Sosial Interaksi Advokat-Klien. Yogyakarta: Pustaka Pelajar.

Widyadharma, I. G. N. R. (2010). Profesional Hukum dalam Pemberian Bantuan Hukum. Semarang: Badan Penerbit Universitas Diponegoro.

Winata, F. H. (2009). Probono Publico, Hak Konstitusional Fakir Miskin untuk Memperoleh Bantuan Hukum. Jakarta: PT Gramedia Pustaka Utama.

YLBHI. (2014). Panduan Bantuan Hukum di Indonesia. Jakarta: Yayasan Obor Indonesia. 


\section{"Equality before the law is probably forever unattainable. It is a noble ideal, but it can never be realized, for what men value in this world is not rights but privileges."}

\section{H.L. Mencken}

\section{Conflicting Interest Statement}

All authors declared that there is no potential conflict of interest on publishing this article.

\section{Funding}

None

\section{Publishing Ethical and Originality Statement}

All authors declared that this work is original and has never been published in any form and in any media, nor is it under consideration for publication in any journal, and all sources cited in this work refer to the basic standards of scientific citation.

Cite this article as:

Lutfiyah, K. (2021). Equality before the Law Principle and the Legal Aid for the Poor: An Indonesian Insight. The Indonesian Journal of International Clinical Legal Education, 3(4), 517-536. https://doi.org/10.15294/ijicle.v3i4.48292 